the pupil. There was a want of sympathy with the learner. For example, the writers on Geography began with the globe, and expounded the elements of Spherical Trigonometry and Astronomy, talking of meridians, parallels, the tropics, the equator, and the ecliptic. At present the best teachers of geography to young children begin with the place where the pupil lives and dwells; thence they proceed to the surrounding districts, to neighbouring countries, and end with the Globe.

Bacon says that "wherever it is possible knowledge should be insinuated into the mind of another in the manner in which it was first discovered." If this principle were fairly carried out it would work great changes in our methods of teaching.

Queen's College, Cork

WILLIAM RUSHTON

\section{MOSS LOCHS}

$A^{\mathrm{s}}$ these lochs are seldom visited save by sportsmen of either the rod or the gun, it will be necessary for me to give a short description of them. These lochs are generally situated high up, near the tops of the hills, the hills being wholly or in part covered with heather and moss. They are of smali size, varying from about a mile to a hundred yards in length; the water is of a dark porter colour. They look as if an immense hole had been dug in the peat, and the hole then filled with water; the banks, which are wholly or in part composed of peat, rising almost perpendicularly out of the water, and at some places extending downwards for many feet under it; at other places going only to a depth of a foot or two, and then extending for some feet in a nearly horizontal direction, when they again dip abruptly to a considerable depth. These abrupt precipices of peat, as seen under the water, are often formed in curious, fantastic shapes, and look more like rock than soft peat; and when seen by the sunshine--broken by the passing waves- through the dusky water, with the surroundings of bleak, bare hill, total silence, save the plaintive cry of some bird passing overhead, and no life, save the lizard and the snake - the whole presents a scene, the weird effect of which on the imagination is seldom if ever exceeded by anything else in nature.

What strikes the observer of these lochs is, that not only are the banks made of peat, but the sides and bottom are wholly or in part made of the same material; and there seems to be no difference between the peat at the bottom of the loch and that on the banks. It looks exactly like as if the peat had begun to be formed at the bottom of the loch, and had gradually extended upwards till it had risen above the water. Yet it could not have done so, because, although water-lilies and some grasses are seen growing under a depth of a foot or two of water, yet all vegetation ceases at a depth of a very few feet. How then came the sides and bottom of these lochs to be formed of peat? There are no signs of any convulsions of nature after the peat had been formed to account for it. If produced by any upheaving of the earth stopping the exit of the water, the upheaving must have been very violent, because many of these lochs are deep and yet of but small size. How, then, came the peat in the position in which we now find it? An examination of the outlet will at once explain the difficulty. The stream which leaves the loch winds its way through mossy ground, the bottom of its channel being covered with water plants. These water plants, as they grow from year to year, are gradually filling up the channel, and so adding to the depth of the loch. It is now easy to understand how peat is found at such depths in these lochs. We will suppose the loch to begin from marshy ground or from a small 1:ch. The channel of the outlet-being covered with water plants-gradually gets filled up, so increasing the depth of the water in the lake, while vegetable life is busy adding peat to the banks. And thus marshy ground or a shallow loch with shelving beach is converted into a deep moss loch with perpendicular sides. The rising of the channel of the outlet and of the sides does not always take place at the same relative rate. In one loch recently visited the peat bank was about eight feet above the water, whilst in another where there was a vigorous growth of water plants in the outlet, the water was within a few inches of being over its banks. That water plants are capable of producing this result will be doubted by none who have seen them fairly establish themselves in a pond, how soon they over-run, and, if left alone, fill it up.

Moss lochs stand in marked contrast to other lochs. In other lochs the water, as it passes from them, has worn their channels, and is year by year wearing them further, so lowering the water in them; whilst in moss lochs the channels are year by year being filled up, so gradually raising the water in them. It may be objected that the water plants in the outlet would be uprooted by the water from the loch during floods; but such is not the case, because in most cases, when the water leaves the loch, it passes through a nearly level channel, so that it never gets up speed sufficient to damage its bed. And besides, these lochs being situated near the tops of the hills, they drain but a small extent of country. In no case visited had any of the lochs a stream of any size running into it, and the amount of water which passed from them was in every case small.

As there are few rules without exceptions, it is possible that the rule that the outlets from moss lochs are covered with water plants may not hold good in every case; it is quite possible that the outlet from a moss loch might be over a rocky channel. If such should happen to be found, it does not necessarily prove that it was not formed in the way shown. The plants might continue to fill up the outlet till the water was raised to such a height that it found a passage over a new channel at a part of the hill where there was no moss and nothing but bare rock. We would thus have a moss loch grown in the way shown, but which had ceased to grow.

JOHN AITKEN

\section{WRITERS ON SCIENCE}

$A T$ the recent dinner of the Royal Literary Fund, Sir A Henry Anderson proposed the toast of "Writers on Science." We make the following extracts from the reply by Dr. Richardson from the report of the Society :-

"Who are the writers on science? Are they as well known as other great writers? They are not. They are less fortunate, and, therefore, the more worthy of the exceptional honour you would bestow on them. Excuse me a moment or two while I indicate the peculiarities of the position of the writer on science. He is a man communicating to the word that which is, by comparison, new to the world. The poet can cast back for his models to a time when the Greeks had not so much as the figment of an alphabet. The theologian may go back for his lesson to the earliest manifestations of the life of intellect on the planet. The historian finds subject and matter ready for his hand from the oldest and remotest, as well as the newest, writings and traditions of races and peoples. The story-teller is embarrassed with the richness of the past, and troubled by the greed of his admirers for more of his work. These all, indeed, are but the continuing interpreters of things. events, thoughts, which every man who claims to read claims also to understand. The writer on science has none of these advantages; he is but newly born into an old world of thought, and is not simply telling of new wonders, but is often himself learning at the same time as he is instructing an audience unlearned in his knowledge. Thus he comes slowly into the recognised 
brotherhood of men of letters; at the best he speaks to but a small audience, amuses rarely, excites sometimes without intention hopes that are delusive, and requires always, in order that he may be fairly understood, a de. gree of patience it is vain to expect from the multitude. To these difficulties others are added belonging to the work he accomplishes. The most original writers on science are destroyed constantly by the magnitude and overpowering character of the work they have written, and by the practical results that spring from the work. In other literature the book produced lives as the book, and the learner from it, age after age, must go back to the fountain head to drink and drink; in science literature the book sinks into the fact it proclaims, and the fact remains the exclusive master of the field. A striking example of this flashes across my mind at the present moment. Every reading man and woman knows that in the reign of Queen Elizabeth the book of Shakespeare's plays had its origin, and nearly everyone who has read the book (and who has not?) remembers the curious saying in it, 'I'll put a girdle round the world in forty minutes.' But how many are there who have read another great book of that same reign, entitled 'De Magnete ;' or are aware that at the time when Shakespeare was writing his now-familiar phrases, the author of the book on the Magnet, the Queen's physician, one William Gilbert, when his daily toils of waiting upon the sick were over, was working with his smith in the laboratory at his furnace, needle, and compass, was writing up for the first time the word 'Electricity' and was actually forging the beginnings of the very instruments that now, in less than forty seconds, put the girdle round the globe? Again, writers on science are lost sometimes in the blaze of their own success. They raise wonder by what they do, and fall beneath it. All knowledge newly born is miracle, but by-and-by, as the knowledge becomes familiar, the miracle ceases. In this way advances in science become part of our lives, while the men who write them down cease to us. When the Leyden jar was first described, Europe was mentally as well as physically convulsed with the thing; now a Leyden jar is a common object-we all know it; but how few know of Mr. Cuneus, who first described this instrument of science? The whole civilised world is cognisant in this day that communication from one part of the world to the other, by telegraph, is almost child's play; but how many have seen or heard of Mr. Cavallo's original Essay on Electricity as a means of communicating intelligence to places distant from each other? There is nothing more commonplace, in our day, than to know that a living human being can be placed in gentle sleep, and, while in blissful oblivion, can have performed on him what were once the tortures of the surgeon's art; but how few have heard or seen Sir Humphry Davy's paperannouncing to mankind this grand beneficence! These are some of the difficulties of writers on science; and yet there is another I must name, be it ever so lightly. I refer to the desperate struggles of the man of science who has nothing but science to carry him on in life. None but such as are placed as I am, practising as physicians in the metropolis of the world, and admitted at the same time, as men of science, into some knowledge of the subject upon which I now speak, can form a conception of the almost hopelessness of the position of the pure scholar of science. On this I say no more. I would awaken but not weary your sympathy .... much of the difficulty these writers have had to bear $\mathrm{I}$ recognise with admiration, as their truest glory; and I see that hope for better worldly prospects is near. A profession of science is no doubt organising. The world is at last asking men of science to employ themselves in teaching the world; and the teachers, bending to the labour, are, in their turn, willing to suspect that they are but as children, or at best youths, in the race after knowledge. This is most hopeful; and it is hopeful also to find that men who claim to be conservators of $a$ knowledge that was matured when science was unborn, are listening now to our scholars with an attentive ear, and are beginning to accept that the Lord of Nature, whether he reveal himself to the ancient law-giver in the burning bush that was not consumed, or to the modern astronomer in the burning glory of the omnipotent sun, is one and the same Lord, Thus there is hope, I may say certainty, in the future for the literature of science; for its poetry, its parables, its facts, nay, even for its religion."

\section{FEARFUL EARTHQUAKE IN CHINA}

THE American Minister in China, General Lowe, has just forwarded to the Secretary of State at Washington the following account of the fearful earthquake which occurred in the Bathang, in the province of Szchuen, on the IIth of April, which he has had translated from the report of the Chinese Governor General of the province in which it occurred:-- Bathang lies on a very elevated spot beyond the province about 200 miles west of Li-Tang, and about thirty post stations from the district town of Ta-tsien, on the high road to Thibet. About eleven o'clock on the morning of the I Ith of April, the earth at Bathang trembled so violently that the government offices, temples, granaries, stone houses, storehouses, and fortifications, with all the common dwellings and the temple of Ting-lin, were at: once overthrown and ruined; the only exception was the hall in the temple grounds, called Ta-Chao, which stood unharmed in its isolation. A few of the troops and people escaped, but most of the inmates were crushed and killed under the falling timber and stone. Flames also suddenly burst out in four places, which strong winds drove about until the heavens were darkened with the smoke, and their roaring was mingled with the lamentations of the distressed people. On the I6th the flames were beaten down, but the rumbling noises were still heard under ground like distant thunder, as the earth rocked and rolled like a ship in a storm. The multiplied miseries of the afflicted inhabitants were increased by a thousand fears, but in about ten days matters began to grow quiet, and the motion of the earth to cease. The grain collector at Bathang says that for several days before the earthquake the water had overflowed the dykes, but after that the earth cracked in many places, and black, fotid water spurted out in a furious manner. If one poked the earth the spurting instantly followed, just as is the case with the salt wells and fire wells in the eastern part of the province; and this explains how it happened that fre followed the earthquake in Bathang. As nearly as can be ascertained there were destroyed two large temples, the offices of the collector of grain tax, the local magistrates' offices, the Ting-lin temple, and nearly 700 fathoms of wall around it, and 351 rooms in all inside; six smaller temples, numbering 22 I rooms, besides 1849 rooms and houses of the common people. The number of people killed by the crash, including the soldiers; was 2,298 , among whom were the local magistrate and his second in office. The earthquake extended from Bathang eastward to Pang. Chahemuth, westward to Nan. Tun, on the south to Lintsah-shih, and on the north to the salt wells to Atimtoz, a circuit of over 400 miles. It occurred simultaneously over the whole of this region. In some places steep hills split and sunk into deep chasms, in others mounds on level plains became precipitous cliffs, and the roads and highways were rendered impassable by obstructions. The people were beggared and scattered like autumn leaves, and this calamity to the people of Bathang and the vicinity was really one of the most distressing and destructive that has ever occurred in China." 